\title{
New trematode Psilochasmus platyrhynchosi (Trematode: Psilochasmidae) from Mallard Anas platyrhynchos (Anseriformes: Anatidae) in Sindh province of Pakistan
}

Saeeda Anjum Buriro ${ }^{1}$, Nadir Ali Birmani ${ }^{1}$ and Abdul Manan Shaikh ${ }^{2}$

1. Department of Zoology, University of Sindh, Jamshoro-Pakistan

2. Department of Zoology, Shah Abdul Latif University Khairpur-Pakistan

*Corresponding author's email: Saeeda.buriro@Scholars.usindh.edu.pk

Citation

Saeeda Anjum Buriro, Nadir Ali Birmani and Abdul Manan Shaikh. New trematode Psilochasmus platyrhynchosi (Trematode: Psilochasmidae) from Mallard Anas platyrhynchos (Anseriformes: Anatidae) in Sindh province of Pakistan. Pure and Applied Biology. Vol. 9, Issue 1, pp1025-1030. http://dx.doi.org/10.19045/bspab.2020.90107

Received: 22/10/2019 Revised: 02/01/2020

Accepted: 08/01/2020

Online First: 18/01/2020

\section{Abstract}

During helminthological studies of Mallard A. platyrhynchos of Hamal Lake, Sindh, Pakistan, twenty-seven birds were examined. The gut contents revealed 32 trematodes belonging to genus Psilochasmus. The morphological features of present specimens differ from congeners in the distribution of vitellaria which is densely arranged in hind body, presence of seminal receptacle, the shape of ovary and size of eggs. Based on these differentiating characters, a new species Psilochasmus platyrhynchosi is proposed.

Keywords: Anas platyrnhnychos; Anatidae; Psilochasmus platyrhnchosi; Pakistan; Sindh

\section{Introduction}

Sindh province, with splendid wetlands and lakes, have been always considered as welcoming grounds for lots of birds who migrate to Pakistan from Russia and Siberia during the winters [1]. Mallard $A$. platyrhynchos is the migratory bird who come from Siberia to Pakistan in winter from October- March. Mallard is a member of order Anseriformes (ducks, geese and swans), generally bound to open waters and wetland habitats. Mallard is migratory in nature and depends upon a variety of food items during migration from Siberia to Asian states. During its stopover habitats, it shares a variety of food items including small invertebrates, tadpoles, small fishes and all type of plant materials [2], Genus Psilochasmus is widespread and cosmopolitan [3]. This genus has been reported from the Greylag Goose Anser anser Linnaeus, 1758 and white-cheeked Pintail Anas bahamensis of Brazil [4]. Brownhooded gull Larus maculipennis of Argentina [5], Common Brahminy duck, Casarca rutile [6], Common Whistling Teal, Dendrocygna javanica of India, [7] and A. platyrhynchos [8] of Pakistan. There is an absence of extensive investigation on helminth parasites of Mallard. Only a few investigations have 
been done but there is a lack of detailed study on helminth parasite of Mallard $A$. platyrhynchos. The main objective of this investigation was to undertake a systematic study to find out the helminth fauna in Mallard, A. platyrhynchos of Hamal Lake. Mallard is an edible bird, it might possible to harbour helminths of medical importance.

\section{Materials and methods}

Live twenty-seven Mallard A. platyrhynchos were collected from Hamal lake Sindh, Pakistan during the winter season from October to March 2018 and examined for the endo-helminths. During the inspection of visceral organs and gut content, a total of 32 flukes of genus Psilochasmus were gathered from the intestine of nineteen positive birds. Flukes were placed in saline $0.9 \%$ solution for a few minutes after that they were put in hot water for relaxing them. Trematodes were then fixed under slight cover glass pressure in alcohol-formalin-acetic acid, borax carmine were used for staining, dehydrated in series of graded ethanol solutions, clove oil and xylol were used for clearing of specimens and Canada balsam was used for mounting. Diagrams were drawn with help of Camera Lucida and photographs were taken with the help of Nikon D700 [9, 10]. All the measurements were taken in millimetre (mm).

\section{Results}

Family Psilochasmidae Loss, 1900

Genus Psilochasmus Luhe, 1909

Psilochasmus platyrhnychosi n.sp.

Description

Body of fluke (Fig. 1) is muscular, elongated with slightly round anterior and tapering posterior end, measuring 3.72- 5.289 X 0.611.052 in size. Fore body is $0.8-1.447$ and hind body 1.6-3.210 in size. Well-developed, muscular, subterminal, laterally elongated oral sucker (Fig. 2) 0.12- 0.342 X 0.11-0.394 in size. Prepharynx short and 0.026 in size. Pharynx round, muscular and almost half of the size of oral sucker $0.06-0.264 \times 0.04$ -
0.263 in size. Esophagus long, diverticulate into intestinal ceca measuring0.43 - 0.657 long. Ventral sucker muscular (Fig. 2), well developed, cup-shaped 0.31-0.605 X 0.410.710 in size.

Testes (Fig. 3) contiguous, tandem, oval and median in shape; anterior testis longitudinally elongated $0.40 \quad-0.605 \quad \mathrm{X} \quad 0.31-0.473$ and posterior testis irregular $0.34-0.657 \mathrm{X} 0.32$ 0.473 in size. Long and tubular cirrus sac 0.61-1.052 X 0.11-0.263 in size. Vitellaria (Fig. 3) dense, starting from ventral sucker's posterior margins reaching up to the posttesticular region, ending in between posterior testis and posterior end of the body, confluent posterior. The ovary (Fig. 3) oval-shaped, pre-testicular smaller than testis 0.11-0.236 X $0.12-0.236$ in diameter. Seminal receptacle oval in shape 0.01-0.184 X 0.013-0.223 in size. Distance between the ovary and ventral sucker 0.736, Post-testicular space is0.50.842 in size and eggs (Fig. 3) small 0.078$0.118 \times 0.005-0.026$ in size.

\section{Taxonomic summary}

Type Host: Mallard A. platyrhynchos (Anseriformes: Anatidae)

Type locality: Hamal Lake, Sindh, Pakistan

Site of infection: intestine

Number of hosts examined: twenty-seven

Number of specimens recovered: thirty two

Etymology: Species name refers to the name of the host bird.

\section{Discussion}

The family Psilostomidae Looss, 1900 is one of the little groups of Echinostomatoid digenetic trematodes existing in mammals and aves. Psilostomidae has been erected by Looss (1900) to incorporate Psilostomum Looss, 1899 involving three species from birds [9] its taxonomic content, structure and constituent genera have been reviewed [11]. Species of Genus Psilochasmus includes $P$. oxyurus (Creplin.,1825) Luhe [12] were collected from A. marila, Phoenicopterusroseus, Botaurusstellaris and A. platyrhynchos of Germany, and from other 
anatids of Europe, U.S, W. Siberia, China, India, Egypt, Azerbaidzhan and Pakistan varies from present specimen having body bluntly round from anterior extremity and pointed posterior extremity, prepharynx absent, esophagus smaller, ventral sucker rounded, seminal receptacle absent, Vitellaria is in the form of large follicles, arranged mainly in extra-caecal field, testis irregular in shape and smaller size of eggs. $P$. singhi Jaiswal and Humayun [7] collected from Common Whistling Teal, Dendrocygnajavanica differs from present specimen in having bluntly rounded anterior end and sharply marked off retractile tail bearing a terminal spine and larger size of body, oral sucker spherical, larger size of prepharynx, oval and larger size of pharynx, ventral sucker round, ovary oval, cirrus sac tubular, seminal receptacle absent, testis notched and larger eggs.
P. aglyptorchis Loos-Frank [13] collected from European herring gull, Larusargentalus differs from the present specimen in having bluntly round anterior extremity slightly posterior tapering, Prepharynx absent, seminal receptacle absent, Vitellaria extends behind the Ventral Suckerto almost posterior half of body, both testes are rounded in shape and smaller eggs. $P$. indicus Gupta [6] collected from common Brahminy duck, Casarca rutile varies from present specimen having posterior extremity with spike, maximum length at testicular level and body larger in size, ovary spherical, Vitellaria extend behind the Ventral sucker to almost posterior half of the body, both testes Constricted in the middle, seminal receptacle absent and smaller eggs size. The comparison of present species with its congener's species is given in (Table 1).

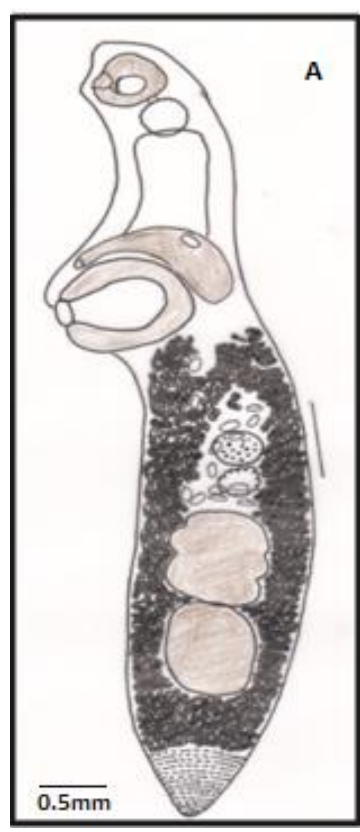

Figure 1. Psilochasmus platyrhynchosi n. sp. Entire worm Diagram. Scale bar: 0.5mm 
Buriro et al.

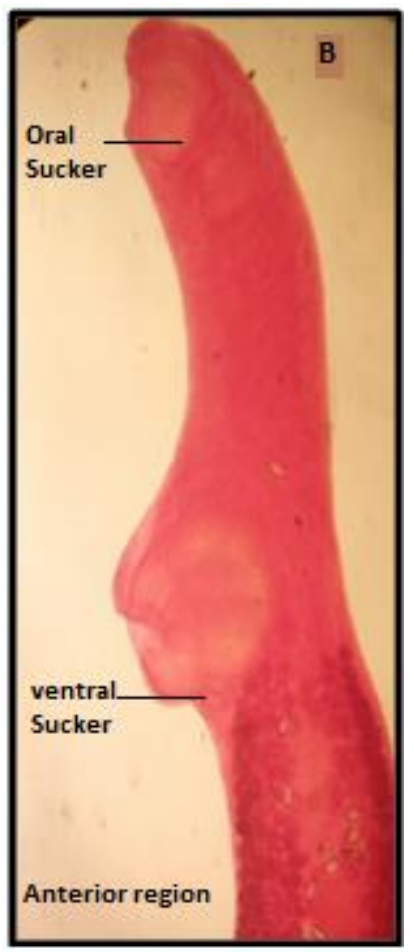

Figure 2. Psilochasmus platyrhynchosi n. sp. Photographs of anterior region

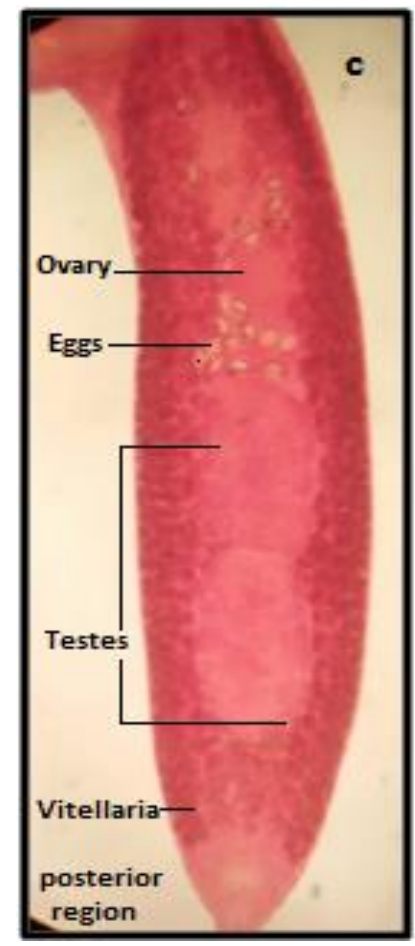

Figure 3. Psilochasmus platyrhynchosi n. sp. Photographs of posterior region 
Table 1. Comparative morphological measurement and features of Psilochamus species

\begin{tabular}{|c|c|c|c|c|c|}
\hline Species & Present species & $\begin{array}{c}P . \text { oxyurus Bhutta } \\
\text { and Khan, } 1975\end{array}$ & $\begin{array}{c}\text { P. indicus Gupta, } \\
1956\end{array}$ & $\begin{array}{c}\text { P. aglyptorchis } \\
\text { Loos- Frank, } 1968\end{array}$ & $\begin{array}{l}P . \text { singhi Jaiswal and } \\
\text { Humayun, } 1971\end{array}$ \\
\hline Body size & $\begin{array}{c}\text { Slightly rounded } \\
\text { anterior and tapering } \\
\text { posterior, end3.72- } \\
5.289 \times 0.61-1.052 \text {. }\end{array}$ & $\begin{array}{l}\text { body has bluntly } \\
\text { round anterior } \\
\text { extremity and } \\
\text { pointed posterior } \\
\text { extremity, } \\
\text { 3.666- } 4.484 \mathrm{X} \\
0.666-0.878\end{array}$ & $\begin{array}{c}\text { Anterior rounded } \\
\text { posterior with } \\
\text { spike, maximum } \\
\text { width at testicular } \\
\text { level, } \\
6.688 \mathrm{X} 0.912\end{array}$ & $\begin{array}{l}\text { Body has bluntly } \\
\text { round anterior } \\
\text { extremity slightly } \\
\text { posterior tapering, } \\
2.875 \times 0.675\end{array}$ & $\begin{array}{c}\text { Bluntly rounded anterior } \\
\text { end and sharply marked } \\
\text { off retractile tail bearing } \\
\text { a terminal spine, } \\
4.806-6.083 \times 0.8399- \\
1.258\end{array}$ \\
\hline Fore body & $0.8-1.447$ & 0.833 & 1.727 & 0.825 & 1.441 \\
\hline Hind body & $1.6-3.210$ & 2.533 & 4.545 & 1.75 & 3.8235 \\
\hline Oral sucker & $\begin{array}{c}\text { Laterally elongated } \\
0.12-0.342 \times 0.11- \\
0.394 \\
\end{array}$ & $\begin{array}{c}\text { Round } \\
0.284-0.343 \mathrm{X} \\
0.245-0.303 \\
\end{array}$ & $\begin{array}{c}\text { Round } \\
0.352 \times 0.384\end{array}$ & $\begin{array}{c}\text { Round } \\
0.225 \times 0.225\end{array}$ & $\begin{array}{c}\text { Round } \\
0.303-0.322 \mathrm{X} 0.296- \\
0.303 \\
\end{array}$ \\
\hline Prepharhynx & $\begin{array}{c}\text { Very short } \\
0.026\end{array}$ & absent & $\begin{array}{c}\text { Short narrow } \\
0.144 \\
\end{array}$ & absent & $\begin{array}{c}\text { Well developed } \\
0.194-0.232 \\
\end{array}$ \\
\hline Pharynx & $\begin{array}{c}\text { Slightly oval } \\
0.06-0.264 \text { X 0.04- } \\
0.263 \\
\end{array}$ & $\begin{array}{c}\text { Oval } \\
0.235-0.245 \times 0.196- \\
0.245 \\
\end{array}$ & $\begin{array}{l}\text { Slightly rounded } \\
0.176 \mathrm{X} 0.192\end{array}$ & $\begin{array}{c}\text { Slightly oval } \\
0.15 \times 0.125\end{array}$ & $\begin{array}{c}\text { Oval } \\
0.245-0.277 \mathrm{X} 0.168- \\
0.187 \\
\end{array}$ \\
\hline Esophagus & $0.43-0.657$ & $\begin{array}{c}\text { short } \\
0.294-0.374\end{array}$ & $\begin{array}{l}\text { long } \\
1.36\end{array}$ & $\begin{array}{l}\text { Short } \\
0.175\end{array}$ & $\begin{array}{c}\text { Long } \\
0.439-0.568\end{array}$ \\
\hline $\begin{array}{l}\text { Ventral } \\
\text { sucker }\end{array}$ & $\begin{array}{c}\text { Cup-shaped } \\
0.31-0.605 \text { X } 0.41- \\
0.710\end{array}$ & $\begin{array}{c}\text { Round } \\
0.490-0.676 \times 0.529- \\
0.598 \\
\end{array}$ & $\begin{array}{c}\text { Oval } \\
0.768 X 0.640\end{array}$ & $\begin{array}{c}\text { Oval } \\
0.275 \times 0.55\end{array}$ & $\begin{array}{c}\text { round } \\
0.477-0.658 \times 0.465- \\
0.580 \\
\end{array}$ \\
\hline Ovary & $\begin{array}{c}\text { Oval } \\
0.11-0.236 \text { X } 0.12- \\
0.236\end{array}$ & $\begin{array}{c}\text { Round } \\
0.156-0.176 \mathrm{X} 0.127- \\
0.176 \\
\end{array}$ & $\begin{array}{c}\text { Round } \\
0.224 \times 0.240\end{array}$ & $\begin{array}{c}\text { Round } \\
0.162 X 0.162\end{array}$ & $\begin{array}{c}\text { Round } \\
0.174-0.213 \text { X } 0.168- \\
0.206 \\
\end{array}$ \\
\hline Cirrus sac & $\begin{array}{c}\text { tubular } \\
0.61-1.052 \times 0.11- \\
0.263 \\
\end{array}$ & $\begin{array}{l}\text { Tubular } \\
0.966 \times 0.1\end{array}$ & $\begin{array}{c}\text { Tubular } \\
1.95 \times 0.227\end{array}$ & $\begin{array}{c}\text { Tubular } \\
0.85 \times 0.125\end{array}$ & $\begin{array}{c}\text { Tubular } \\
1.411 \times 0.088\end{array}$ \\
\hline $\begin{array}{l}\text { Seminal } \\
\text { receptacle }\end{array}$ & $\begin{array}{c}\text { Oval } \\
0.01-0.184 \text { X } 0.013- \\
0.223\end{array}$ & absent & Absent & absent & absent \\
\hline Ant: testis & $\begin{array}{c}\text { Irregular } \\
0.40-0.605 \text { X } 0.31- \\
0.473\end{array}$ & $\begin{array}{c}\text { Lobed and irregular } \\
0.392-0.450 \times 0.245- \\
0.372\end{array}$ & $\begin{array}{c}\text { Rounded } \\
0.480 \times 0.352\end{array}$ & $\begin{array}{c}\text { Slightly rounded } \\
0.375 \times 0.3\end{array}$ & $\begin{array}{c}\text { Notched } \\
0.458-0.529 \times 0.258- \\
0.374\end{array}$ \\
\hline Post: testis & $\begin{array}{c}\text { Longitudinally } \\
\text { elongated } \\
0.34-0.657 \mathrm{X} \\
0.320 .473 \\
\end{array}$ & $\begin{array}{c}\text { Lobed and irregular } \\
0.470-0.490 \times 0.196- \\
0.372\end{array}$ & $\begin{array}{c}\text { Oval } \\
0.496 \times 0.288\end{array}$ & $\begin{array}{c}\text { Oval } \\
0.375 \times 0.3\end{array}$ & $\begin{array}{c}\text { Notched } \\
0.490-0.664 \text { X0.264 - } \\
0.348\end{array}$ \\
\hline Vitellaria & $\begin{array}{c}\text { dense, } \\
\text { commencing from } \\
\text { posterior margins of } \\
\text { ventral sucker } \\
\text { reaching up to the } \\
\text { post-testicular region }\end{array}$ & $\begin{array}{l}\text { In the form of large } \\
\text { follicles, arranged } \\
\text { mainly in extra- } \\
\text { caecal field. }\end{array}$ & $\begin{array}{l}\text { extend behind the } \\
\text { V.S to almost } \\
\text { posterior half of } \\
\text { the body }\end{array}$ & $\begin{array}{l}\text { extend behind the } \\
\text { V.S to almost } \\
\text { posterior half of the } \\
\text { body }\end{array}$ & $\begin{array}{l}\text { extend behind the V.S to } \\
\text { almost posterior half of } \\
\text { the body }\end{array}$ \\
\hline Eggs & $\begin{array}{c}0.078-0.118 X \\
0.005-0.026\end{array}$ & $\begin{array}{c}\text { long } \\
0.078-0.109 \times 0.056- \\
0.078\end{array}$ & $\begin{array}{c}\text { Short } \\
0.080- \\
0.096 \times 0.046- \\
0.064 \\
\end{array}$ & $\begin{array}{c}\text { Short } \\
0.05-0.075 \\
\mathrm{X} 0.0125 \mathrm{X} 0.025\end{array}$ & $\begin{array}{c}\text { Long } \\
0.09-0.12 \mathrm{X} 0.07- \\
0.072\end{array}$ \\
\hline Host & Anasplatyrhynchos & Anasplatyrhynchos & Casarcarutila & Larusargentalus & Dendrocygnajavanica \\
\hline Location & Small intestine & Intestine & Intestine & Intestine & intestine \\
\hline Locality & Hamal lake & $\begin{array}{l}\text { Ballokiheadworks } \\
\text { area } \\
\end{array}$ & India & Helogoland & India \\
\hline
\end{tabular}




\section{Conclusion}

Genus Psilochasmus recorded for the second time from avian host Mallard, $A$. platyrhynchos. New report will help to understand diversity of trematodes in avian fauna of Pakistan.

\section{Authors' contributions}

Conceived and designed the experiments: SA Buriro \& NA Birmani, Performed the experiments: SA Buriro, Analyzed the data: SA Buriro \& NA Birmani, Contributed materials/ analysis/ tools: SA Buriro, NA Birmani \& AM Shaikh, Wrote the paper: SA Buriro.

\section{Reference}

1. Birmani N, Dharejo A \& Khan M (2011). Catatropis sp. (Trematoda: Notocotylidae) from the Black Coot, Fulica atra Linnaeus, 1758 (Gruiformes: Rallidae) in Sindh Province of Pakistan. JAPS, J of Animal and Plant Sci 21(4): 872-873.

2. Buriro SA, Birmani NA, Shaikh AM\& Dharejo AM (2016). Two digenetic trematodes with description of a new species from Anas platyrhynchos (Anseriformes: Anatidae) in Sindh, Pakistan.J of Entomol and Zool Stud 4(5): 734-737.

3. Alda P, Martorelli SR \& Sarria R(2011). Digenean Parasites in the White-Backed Stilt Himantopus melanurus Vieillot, 1817 (Recurvirostridae) from the Argentine Coast. Comparative Parasitol 78(1): 217-220.

4. Fernandes BM, Menezes RC, Tortelly R, Noronha D \& Pinto RM (2007). First report of the digenetic trematode Psilochasmus oxyurus (Creplin) in the domestic goose, Anser anser (Linnaeus) in South America. Revista Brasileira de Zool 24(2): 520-522.
5. Labriola J \& Suriano D (2001). Community structure of parasitic helminths of birds of the genus Larus from Mar del Plata, Argentina. Vie et Milieu 51: 67-76.

6. Gupta P (1957). On Psilochasmus indicus, sp. n.(family Psilostomidae Odhner, 1913). Parasitol 47(3-4): 452456.

7. Jaiswal GP \& Humayun MRA (1971). Investigations on the Trematode Fauna of Hyderabad, AP Part II. Parasites of Birds-(C). Psilochasmus singhi sp. n. from a Common Whistling Teal, Dendrocygna javanica. Proc Helm Soc Wash 38(2): 236-239.

8. Bhutta MS \& Khan D (1975). Digenetic trematodes of vertebrates from Pakistan. Bull Deppt of Zool Uni of Punjab (NS) 8: 1-175.

9. Garcia L \& Ash L (1979). Diagnostic parasitology: clinical laboratory manual. the CV Mosby company. 11830 Westline industrial drive, St. Louis, Missouri 63141.

10. Schmidt G (1988). Essentials of parasitology 4th Edition. Wm. C. Brown Publishers, 2460, Keper Boulevard, Dubuque, IA 52001, pp 294.

11. Jones A, Bray RA \& Gibson DI (2002). Keys to the Trematoda (Vol 1): CABI Publishing and The Natural History Museum.

12. Yamaguti S (1971). Synopsis of digenetic trematodes of vertebrates. Vols I and II. Synopsis of Digenetic Trematodes of Vertebrates.

13. Loos-Frank B (1968). Psilochasmus aglyptorchis $\mathrm{n}$. $\quad$ sp.(Trematoda, Psilostomidae) und sein Entwicklungszyklus. Zeitschrift für Parasitenkunde 30(3): 185-191. 